\title{
Omega $3(n-3)$ fatty acids down-regulate nuclear factor-kappa B (NF-KB) gene and blood cell adhesion molecule expression in patients with homozygous sickle cell disease ${ }^{\text {th }}$
}

\author{
Ahmed A. Daak a,b,c,*, Abozer Y. Elderdery ${ }^{\mathrm{d}}$, Leana M. Elbashir ${ }^{\mathrm{b}}$, Katia Mariniello ${ }^{\mathrm{a}}$, Jeremy Mills ${ }^{\mathrm{d}}$, \\ Garry Scarlett $^{\mathrm{d}}$, Mustafa I. Elbashir ${ }^{\mathrm{b}}$, Kebreab Ghebremeskel ${ }^{\mathrm{a}}$ \\ a Lipidomics and Nutrition Research Center, Faculty of Life Sciences and Computing, London Metropolitan University, London, UK \\ ${ }^{\mathrm{b}}$ Department of Medical Biochemistry, Faculty of Medicine, University of Khartoum, Sudan \\ ${ }^{\text {c } H a r v a r d ~ S c h o o l ~ o f ~ P u b l i c ~ H e a l t h, ~ H a r v a r d ~ U n i v e r s i t y, ~ U S A ~}$ \\ d School of Pharmacy and Biomedical Sciences, Faculty of Science, University of Portsmouth, UK
}

\section{A R T I C L E I N F O}

\section{Article history:}

Submitted 19 January 2015

Revised 29 March 2015

Accepted 29 March 2015

Available online 31 March 2015

\section{Keywords:}

Sickle cell disease

Omega- 3 and omega- 6 fatty acids

Inflammation

Blood cell adhesion

Nuclear factor-kappa B (NF-kB)

\begin{abstract}
A B S T R A C T
Chronic inflammation and reduced blood levels of omega-3 fatty acids $(n-3)$ are known characteristics of sickle cell disease (SCD).The anti-inflammatory properties of $n-3$ fatty acids are well recognized. Omega-3 treated $(n=24)$, hydroxyurea $(H U)$ treated $(n=18)$, and $n-3$ untreated $(n=21)$ homozygous SCD patients (HbSS) and healthy (HbAA) controls $(\mathrm{n}=25)$ matched for age (5-16 years), gender and socioeconomic status were studied. According to age (5-10) or (11-16) years, two or three capsules containing $277.8 \mathrm{mg}$ docosahexaenoic (DHA) and $39.0 \mathrm{mg}$ eicosapentaenoic (EPA) or high oleic acid placebo (41\%) were assigned to $n-3$ treated and $n-3$ untreated groups, respectively. Hydroxyurea treated group was on dosage more than $20 \mathrm{mg} / \mathrm{kg} /$ day. The effect of supplementation on systemic and blood cell markers of inflammation was investigated.

The $n-3$ treated group had higher levels of DHA and EPA $(p<0.001)$ and lower white blood cell count and monocyte integrin $(p<0.05)$ compared with the $n-3$ untreated. No difference was detected between the two groups regarding $C$-reactive protein, granulocytes integrin and selectin, plasma tumour necrosis factor- $\alpha$ and interleukin-10. The $n-3$ treated group had lowered nuclear factor-kappa $B(N F-\kappa B)$ gene expression compared to $\mathrm{n}-3$ untreated and $\mathrm{HU}$ treated groups $(\mathrm{p}<0.05)$.

This study provides evidence that supplementation with $\mathrm{n}-3$ fatty acids may ameliorate inflammation and blood cell adhesion in patients with SCD.
\end{abstract}

(c) 2015 Elsevier Inc. All rights reserved.

\section{Introduction}

The classical paradigm of sickle cell disease (SCD) pathophysiology has always considered haemoglobin $\mathrm{S}(\mathrm{HbS})$ polymerisation and red cell sickling as the primary causative factor of acute and chronic complications associated with the disease [1]. Though, recent advances in SCD research have revealed a more complex pathophysiology of the disease [2-4]. Indeed, it has been demonstrated that inflammation and increased leukocyte-erythrocyte-endothelial interactions are the major potential initiating mechanisms of recurrent occlusion of blood vessels [5,6]. In addition, the therapeutic effect of hydroxyurea, the

\footnotetext{
Source of support• Efamol Limited UK• Mother and Child Foundation, UK• The Kitchner Memorial Trust Fund supported Ahmed A Daak

* Corresponding author at: Department of Medical Biochemistry, Faculty of Medicine, University of Khartoum, Alghasr Street, Khartoum, Sudan.

E-mail addresses: ahmed.malik@meduofk.net, adaak@hsph.harvard.edu (A.A. Daak).
}

common treatment for SCD, and some emerging experimental treatments is chiefly attributed to their anti-inflammatory and anti-adhesive properties [7-10].

The beneficial effects of long-chain omega-3 polyunsaturated fatty acids ( $n-3)$, such as eicosapentaenoic acid (EPA) and docosahexaenoic acid (DHA), on chronic inflammatory disorders are well recognized [11]. Moreover, studies have revealed that supplementation with omega-3 fatty acids can decrease production of pro-inflammatory cytokines and adhesive molecules [11-13]. Interestingly, research on patients with SCD invariably found a high $n-6 / n-3$ ratio in blood cells and plasma. These findings indicated the important role of fatty acid abnormality in the chronic inflammatory state associated with the disease $[14,15]$. In addition, our group and others have shown that supplementing SCD patients with omega- 3 fatty acids corrects cell membrane abnormalities and confer protection against vaso-occlusive pain episodes, severe anaemia and oxidative stress [16-19], and improves red blood cells flexibility in mice [20]. However, little is known about the potential antiinflammatory role of $n-3$ fatty acids in SCD. 
The mechanisms by which omega- 3 fatty acids exert their antiinflammatory effects are not fully understood. Nevertheless, mounting evidence indicates the importance of nuclear factor-kappa B (NF-kB) gene [21,22], a key transcription factor involved in the up-regulation of inflammatory cytokines and adhesive molecules genes [23]. Therefore, we postulated that the observed therapeutic effect of omega-3 fatty acids supplementation on sickle cell disease could partly implicate suppression of NF- $\kappa \mathrm{B}$ gene transcription and adhesive molecule expression in patients with SCD.

In this study, we investigated a) whether supplementation with $\mathrm{n}-3$ DHA and EPA ameliorates systemic markers of inflammation and blood cells adhesion and b) modulates NF- $\kappa$ B gene expression.

\section{Methods}

\subsection{Subjects}

This study was conducted in the context of a single centre, two-arms, randomised, placebo-controlled, double blinded clinical trial [16]. Steady state homozygous (HbSS) sickle cell patients (who did not experience painful crisis or other acute medical condition for at least 1 month) were enrolled in Ibn-Aoaf Paediatric Hospital, Khartoum, Sudan. Haemoglobin phenotype of patients (HbSS) and healthy controls (HbAA) was confirmed by cellulose acetate electrophoresis. The patients were on regular folate supplement, before and after enrolment. The exclusion criteria were: other chronic diseases and receiving blood transfusion in the previous four-months. The group on omega-3 fatty acid received, according to age, a daily dosage of $500-750 \mathrm{mg}$ capsules containing $277.8 \mathrm{mg}$ DHA and $39.0 \mathrm{mg}$ EPA. The placebo group received capsules containing high oleic acid (41\%) oil blend. Vitamin E (1.5 mg/capsule) was added to both types of capsules to prevent fatty acid peroxidation. SCD patients on hydroxyurea treatment were on dosage more than $20 \mathrm{mg} / \mathrm{kg} /$ day. The three groups of patients were on their respective treatment for a minimum of one year.

Omega-3 fatty acid treated $(\mathrm{n}=24)$, hydroxyurea treated $(\mathrm{n}=18)$ and placebo (untreated) group $(\mathrm{n}=21)$ HbSS patients and healthy ( $\mathrm{HbAA}$ ) controls $(\mathrm{n}=25)$ matched for age ( $5-17$ years), gender, ethnicity and socio-economic background were included in the study. The expression of adhesive molecules was studied in a subgroup of omega-3 treated $(n=10)$ and untreated $(n=10)$ matched for age (1117 years) and gender before and after intervention.

After an overnight fast and according to age that is less or above 11 years old, $5 \mathrm{ml}$ or $15 \mathrm{ml}$ of whole blood was taken from the patients and controls in EDTA tubes under sterilized conditions.

The Research Board of the Faculty of Medicine, University of Khartoum, Sudan, approved the study. In addition, approval has been obtained from National Research Ethics Service, Southampton \& South West Hampshire Research Ethics Committee (A) UK (REC reference: 05/Q1702/48). Informed written consents were obtained from the participants or their guardians.

\subsection{Preparation of the samples}

The whole blood ( $5 \mathrm{ml}$ ) was fractionated into red blood cells (RBCs) and plasma by cold centrifugation at $3000 \mathrm{rpm}$ for $15 \mathrm{~min}$. The top plasma layer was carefully syphoned off and transferred into another tube. The buffy coat was removed and transferred to a new tube containing 0.5 of RNA later (Sigma, UK) for RNA stabilisation. The lower red cell layer was washed three times with physiological saline $(0.85 \% \mathrm{NaCl})$ and centrifuged to remove traces of plasma and buffy coat. The resulting plasma and $\mathrm{RBC}$ pellet were thoroughly flushed under oxygen-free nitrogen and immediately stored at $-80^{\circ} \mathrm{C}$ until analysis.

$10 \mathrm{ml}$ of whole blood was used to obtain monocytes and granulocytes through a sequence of centrifugation steps using histopaque-1077 (density $1.077 \mathrm{~g} / \mathrm{ml}$ ) and histopaque-1119 (density $1.119 \mathrm{~g} / \mathrm{ml}$ ) (SigmaAldrich, UK). Firstly, $3 \mathrm{ml}$ of histopaque- 1119 was added to a $50 \mathrm{ml}$ tube followed by $3 \mathrm{ml}$ of histopaque-1077 to form two distinct phases. Consequently, $5 \mathrm{ml}$ of the collected whole blood was layered carefully over the histopaque and centrifuged at $700 \times g$ for $50 \mathrm{~min}$ at $22^{\circ} \mathrm{C}$ (room temperature). Separation of plasma, mononuclear cells/platelets, granulocytes and red blood cells was obtained. The top layer (plasma) was transferred to cryotubes and stored at $-80^{\circ} \mathrm{C}$. The mononuclear cells/platelets fraction was transferred to a new tube and re-suspended in $10 \mathrm{ml} 1 \times$ phosphate buffer saline $(1 \times$ PBS) (Sigma-Aldrich, UK) and centrifuged at $250 \times \mathrm{g}$ for $10 \mathrm{~min}$ at $22^{\circ} \mathrm{C}$. The supernatant (platelets) was transferred to a new $15 \mathrm{ml}$ tube, whereas the remaining pellet was re-suspended with $10 \mathrm{ml} 1 \times$ PBS and washed twice by centrifugation at $250 \times \mathrm{g}$ for $10 \mathrm{~min}$. Mononuclear cells and granulocytes were washed twice with $10 \mathrm{ml} 1 \times$ PBS at $2000 \times \mathrm{g}$ for $5 \mathrm{~min}$ and resuspended in $450 \mu \mathrm{l} \mathrm{serum} \mathrm{ob-}$ tained from the same blood sample and $50 \mu \mathrm{l}$ dimethyl sulfoxide (DMSO). Red blood cells were washed three times with normal saline $(0.85 \% \mathrm{NaCl})$ and centrifuged at $3000 \mathrm{rpm}$ to remove traces of plasma and buffy coat. The resulting plasma and $\mathrm{RBC}$ were stored at $-80^{\circ} \mathrm{C}$, whilst mononuclear cells and granulocytes were stored in liquid nitrogen, until the analysis.

\subsection{Haematological parameters}

Before sample processing, Hb concentration, white blood cell count (WBC) and platelet count were obtained by using an automated haematology analyser Sysmex KX-21N (Sysmex Corporation, Kobe, Japan).

\subsection{Analysis of red blood cell fatty acids}

Total lipids were extracted by the method of Folch et al. (1957); the detailed methodology was desecrated in our previous publication [14].

\subsection{C-reactive protein (CRP) assay}

C-reactive protein was assayed by using commercially available enzyme-linked immunosorbent i-Chroma hsCRP test kits and an i-CHROMA reader (Boditech, Korea).

\subsection{Measurements of plasma tumour necrosis factor- $\alpha$ (TNF- $\alpha$ ) and interleukin-10 (IL-10)}

Commercially available enzyme-linked immunosorbent assay (ELISA) kits were used to determine TNF- $\alpha$ and IL-10 plasma concentration (Pierce Biotechnology, Rockford, USA). All samples were analysed simultaneously using the same kits under the same analytical conditions.

\subsection{Assessing $\beta 2$-integrin $C D 11 \mathrm{~b} / C 18$ (CD-11b) and L-selectin (CD62L) expression in granulocytes and monocytes}

Mononuclear cells and granulocytes were quickly defrosted at $37^{\circ} \mathrm{C}$. $200 \mu \mathrm{l}$ of each defrosted sample was washed in $10 \mathrm{ml} 1 \times$ PBS by centrifugation at $400 \times \mathrm{g}$ for $5 \mathrm{~min}$. The supernatant was discarded, and the pellet was suspended in $1 \mathrm{ml} 1 \times \mathrm{PBS} / \mathrm{BSA} 2 \mathrm{mg} / \mathrm{ml}$ (Sigma-Aldrich Co. UK., A7906). $50 \mu \mathrm{l}$ of cell suspension was incubated on a shaker with $10 \mu \mathrm{l}$ (used as supplied) of anti-human-CD11b fluorescein isothiocyanate (FITC) conjugated antibody, anti-human-CD62L-FITC, or mouse anti-IgG, at $4{ }^{\circ} \mathrm{C}$ for one hour in the dark. Cells were also incubated with no antibody at the same conditions, and used as negative control. After incubation, cells were washed three times in $1.5 \mathrm{ml} 1 \times \mathrm{PBS}$, by centrifugation at $150 \times \mathrm{g}$ for $5 \mathrm{~min}$. Cell pellet was resuspended in $200 \mu \mathrm{l} 1 \times$ PBS, and used for flow cytometry analysis.

In order to standardise the positioning of monocytes, micro beads conjugated to anti-Human-CD14 antibody were used for monocyte purification (Miltenyi Biotec GmbH, Germany). $10^{7}$ total mononuclear cells counted by microscope visualization using a counting chamber were suspended in $80 \mu \mathrm{l}$ of incubation buffer (0.5\% BSA, $2 \mathrm{mM}$ EDTA in $1 \times$ PBS pH 7.2), and incubated with CD14 micro beads for $30 \mathrm{~min}$ 
at $4{ }^{\circ} \mathrm{C}$, on a shaker in the dark. Subsequently, cells were washed three times in incubation buffer by centrifugation at $300 \times \mathrm{g}$ for $10 \mathrm{~min}$. Cells were resuspended in $500 \mu \mathrm{l}$ of incubation buffer. Cells bound to CD14 micro beads were sequestered by the use of a column placed in a magnetic field separator (Miltenyi Biotec $\mathrm{GmbH}$, Germany). Cells were eluted by washing the column with $1 \mathrm{ml}$ of incubation buffer. Cells were precipitated at $300 \times \mathrm{g}$, diluted in $1 \times \mathrm{PBS} / \mathrm{BSA} 2 \mathrm{mg} / \mathrm{ml}$, and labelled with anti-human-CD11b FITC conjugated anti-bodies. The fluorescent signal from the purified monocytes was compared to the same non-purified sample.

Samples were loaded into 96-well plates in duplicates, and expressions of CD11b and CD62L were measured by flow cytometry using the GUAVA PCA-96 flow cytometer and GUAVA express plus software (Guava technologies, UK). An optical emission filter for $580-583 \mathrm{~nm}$ was used to detect FITC fluorescence. Over 5000 cells were submitted to analysis at each trial. Unlabelled cells and IgG labelled cells were used as the negative control for non-specific flow cytometry background. Monocytes and granulocytes cells were gated carefully based on forward scatter and side scatter. We could not measure expression of CD62L in monocytes because we did not have enough samples to conduct the analysis.

2.8. RNA isolation and Reverse Transcription-Polymerase Chain Reaction $(P C R)$

RNA was isolated from peripheral blood cells using RNAqueous Kit according to the manufacturer's instructions (Ambion). RNA integrity was checked by using $2 \%$ agarose gel electrophoresis. First strand cDNA synthesis was performed using $1 \mu \mathrm{L}$ total RNA and $300 \mathrm{ng} / \mu \mathrm{L}$ random primers and SuperScript III Reverse Transcriptase (Life Technologies) as per manufacturer's instructions. The resultant cDNA stored at $-20^{\circ} \mathrm{C}$.

\subsection{Quantitative Real-time Polymerase Chain Reaction}

Real-time quantitative PCR of the cDNA template was performed in an ABI Prism 7000 SDS (Applied Biosystems) run by software SDS-2.3. The PCR reaction contained $4 \mu \mathrm{L}$ of cDNA, $20 \mu \mathrm{L}$ reaction mix (Rob mix, $\mathrm{ABI})$. The PCR cycling conditions were: $95^{\circ} \mathrm{C}(15 \mathrm{~s}), 58^{\circ} \mathrm{C}(20 \mathrm{~s}), 72{ }^{\circ} \mathrm{C}$ $(25 \mathrm{~s})$ for 35 cycles. Results were calculated as expression of the target gene $(\mathrm{NF}-\kappa \mathrm{B})$ relative to expression of the reference gene (GAPDH).

\subsection{Data analysis}

The data were described by mean \pm SD or median and interquartile rage (IQR) as pertinent. The three groups were compared for NF- $\kappa \mathrm{B}$ gene expression, TNF- $\alpha$ and CRP level by using one-way analysis of variance (ANOVA). When statistical differences were indicated, Tamhane's T2 pairwise multiple comparison post-hoc tests were performed. Nonparametric test related-sample Wilcoxon signed ranks was applied to explore differences in fatty acids, haematological profile, TNF- $\alpha$, IL-10 and adhesive molecule levels before and after intervention. Independent sample Mann-Whitney $U$ test was used to test the effect of supplementation on fatty acid composition and adhesive molecules between the groups. The statistical significance was assumed at a p-value of less than 0.05. The statistical software, SPSS for Windows, Version 19 (SPSS Ltd., Surrey, UK) was used to analyse the data.

\section{Results}

3.1. Fatty acid composition of red blood cell phosphatidyl ethanolamine $(P E)$ and choline $(P C)$

The fatty acid compositions of red blood cells PE and PC at baseline and after one year of supplementation with $n-3$ treated and untreated (placebo) groups were included in Table 1 . The fatty acid profile of the $\mathrm{n}-3$ treated and untreated groups was comparable at base-line ( $p>0.05$ ). In $n-3$ treated group, DHA and EPA increased three-fold in red cell choline $(\mathrm{PC})$ and ethanolamine $(\mathrm{PE})$ phosphoglycerides compared with the baseline $(\mathrm{p}<0.001)$, whereas arachidonic acid (AA) and total $n-6$ FAs were significantly reduced in PE and PC $(p<0.001)$. Intervention had no effect on PE fatty acid profile after one year of supplementation $(p>0.05)$ in $n-3$ untreated. However, significant increase in total $\mathrm{n}-6$ and decrease in EPA of PC phosphoglyceride were detected in $n-3$ untreated group after one year of supplementation in comparison to baseline.

\subsection{Haematological parameters}

Supplementation with $\mathrm{n}-3$ and placebo increased $\mathrm{Hb}$ concentration $(\mathrm{p}<0.001)$. In contrast to the placebo group, $\mathrm{n}-3$ supplements caused significant reduction on total white blood cells (TWBC) $(P<0.05)$. Both $\mathrm{n}-3$ treated and untreated groups, intervention showed no effect on platelet count, Table 1.

\subsection{Effect of $n-3$ supplementation on plasma C-reactive protein levels (CRP)}

Both treated and untreated groups of patients had higher concentrations of $\mathrm{C}$-reactive protein compared with their healthy controls ( $p<0.001$ ). There was no significant difference in plasma CRP concentrations between the supplemented and un-supplemented patients $(\mathrm{p}>0.05)$, Fig. 1 .

\subsection{Plasma levels of tumour necrosis factor- $\alpha$ (TNF- $\alpha$ ) in hydroxyurea (HU) treated and untreated group}

The HbSS treated with hydroxyurea had a significantly higher level $(\mathrm{p}<0.05)$ of TNF- $\alpha$ in comparison to the untreated group (Median $=$ $41.7(\mathrm{IQR}=24.4) \mathrm{pg} / \mathrm{ml}$ vs Median $=14.7(\mathrm{IQR}=19.6) \mathrm{pg} / \mathrm{ml})$ and $\mathrm{n}-3$ treated group $($ Median $=41.7(\mathrm{IQR}=24.4) \mathrm{pg} / \mathrm{ml}$ vs Median $=$ $15.8(\mathrm{IQR}=8.8) \mathrm{pg} / \mathrm{ml})$, Fig. 2.

3.5. Plasma levels of tumour necrosis factor- $\alpha$ (TNF- $\alpha$ ) and interleukin-10 (IL-10) in $n-3$ treated, HU treated and untreated groups

Supplementation with $\mathrm{n}-3$ fatty acids had no effect on plasma TNF- $\alpha$ $(18.6 \pm 12.8$ vs $17.8 \pm 9.1)(p>0.05$, Fig. $3 a)$ and IL-10 $(11.0 \pm 4.3$ vs $11.3 \pm 5.8$ ) compared to baseline levels $(p>0.05)$, Fig. $3 b$.

\subsection{Expression of $\beta 2$-integrin $C D 11 b / C 18(C D-11 b)$ in monocytes at baseline}

The level of adhesive molecules of placebo and active group were comparable at baseline ( $p>0.05$ ), Fig. $4 a$ and $b$.

After one year of supplementation with $n-3$, CD11b expression in monocytes were significantly lower compared to placebo and baseline $(\mathrm{P}<0.05)$, Figs. $4 \mathrm{a}$ and 5 , respectively.

\subsection{Expression of $\beta 2$-integrin $C D 11 b / C 18$ (CD-11b) and L-selectin (CD62L) in granulocytes}

The level of adhesive molecules of placebo and active group were comparable at baseline $(p>0.05)$. Supplementation with $n-3$ or placebo caused no significant effect on CD11b and CD62L expression in granulocytes ( $p>0.05)$, Figs. $4 b$ and 5 .

\subsection{Effect of omega-3 fatty acids and HU treatments on gene expression of white blood cell NF- $\kappa B$ gene}

Treatment with $\mathrm{n}-3$ fatty acid resulted in a significant reduction in $\mathrm{NF}-\kappa \mathrm{B}$ gene relative fold gene expression in comparison to $n-3$ 
Table 1

Fatty acid composition of red blood cell phosphatidyl ethanolamine (PE) and choline (PC) and blood cell count at baseline and the end of one year intervention period.

\begin{tabular}{|c|c|c|c|c|}
\hline \multirow[b]{2}{*}{ Measure } & \multicolumn{2}{|c|}{$\mathrm{n}-3$ treated, $\mathrm{n}=19$} & \multicolumn{2}{|c|}{ Untreated (placebo group), $\mathrm{n}=18$} \\
\hline & Baseline & One year & Baseline & One year \\
\hline \multicolumn{5}{|l|}{ Fatty acids-PE } \\
\hline C18:2n-6 & $5.2 \pm 0.8$ & $5.2 \pm 0.6$ & $4.6 \pm 0.6$ & $5.0 \pm 0.8$ \\
\hline$C 20: 4 n-6$ & $24.1 \pm 1.2$ & $22.2 \pm 1.9^{* * *}$ & $23.9 \pm 1.4$ & $24.5 \pm 0.7$ \\
\hline$C 22: 4 n-6$ & $10.7 \pm 1.2$ & $7.2 \pm 2.3^{* * *}$ & $10.3 \pm 0.3$ & $10.2 \pm 0.2$ \\
\hline Total $n-6$ & $44.5 \pm 1.2$ & $36.9 \pm 3.7^{* * *}$ & $43.3 \pm 1.2$ & $43.7 \pm 1.5$ \\
\hline$C 20: 5 n-3$ & $0.1 \pm 0.04$ & $0.3 \pm 0.2^{* * *}$ & $0.1 \pm 0.03$ & $0.1 \pm 0.02$ \\
\hline$C 22: 5 n-3$ & $1.7 \pm 0.3$ & $1.4 \pm 0.2^{* * *}$ & $1.7 \pm 0.3$ & $1.6 \pm 0.1$ \\
\hline$C 22: 6 n-3$ & $2.5 \pm 0.7$ & $8.8 \pm 2.8^{* * *}$ & $2.8 \pm 9.4$ & $2.5 \pm 0.2$ \\
\hline Total $n-3$ & $4.4 \pm 0.9$ & $10.6 \pm 3.2^{* * *}$ & $4.7 \pm 0.4$ & $4.2 \pm 0.2$ \\
\hline \multicolumn{5}{|l|}{ Fatty acids-PC } \\
\hline$C 18: 2 n-6$ & $15.7 \pm 2.3$ & $18.1 \pm 2.18^{* * *}$ & $17.5 \pm 2.5$ & $19.2 \pm 3.5$ \\
\hline$C 20: 4 n-6$ & $9.9 \pm 1.0$ & $7.9 \pm 1.2^{* * *}$ & $9.6 \pm 0.4$ & $8.8 \pm 1.3$ \\
\hline$C 22: 4 n-6$ & $1.1 \pm 0.2$ & $0.6 \pm 0.2^{* * *}$ & $0.82 \pm 0.05$ & $0.6 \pm 0.2^{*}$ \\
\hline Total $n-6$ & $29.5 \pm 1.9$ & $28.8 \pm 2.7^{*}$ & $30.6 \pm 2.6$ & $32.1 \pm 2.8^{*}$ \\
\hline$C 20: 5 n-3$ & $0.1 \pm 0.04$ & $0.24 \pm 0.1^{* * *}$ & $0.08 \pm 0.05$ & $0.04 \pm .01^{*}$ \\
\hline$C 22: 5 n-3$ & $0.3 \pm 0.06$ & $0.2 \pm 0.1^{* * *}$ & $0.3 \pm 0.03$ & $0.2 \pm 0.08$ \\
\hline$c 22: 6 n-3$ & $0.7 \pm 0.2$ & $2.6 \pm 0.9^{* * *}$ & $0.7 \pm 0.2$ & $0.6 \pm 0.3$ \\
\hline Total $n-3$ & $1.2 \pm 0.3$ & $3.1 \pm 1.1^{* * *}$ & $1.2 \pm 0.2$ & $0.8 \pm 0.3$ \\
\hline \multicolumn{5}{|c|}{ Blood cell count } \\
\hline $\mathrm{Hb} \mathrm{g} / \mathrm{l}$ & $64.5 \pm 7.5$ & $76.2 \pm 6.8^{* * *}$ & $67.4 \pm 7.6$ & $76.3 \pm 11.3^{\text {*** }}$ \\
\hline $\mathrm{TWBC}^{*} 10^{3}$ & $15.3 \pm 3.5$ & $14.1 \pm 2.8^{*}$ & $13.2 \pm 3.8$ & $14.2 \pm 4.3$ \\
\hline PLTs ${ }^{*} 10^{3}$ & $524.3 \pm 141.4$ & $487.6 \pm 141.4$ & $509.6 \pm 232.9$ & $484.5 \pm 217.5$ \\
\hline
\end{tabular}

* $\mathrm{P}<0.05$.

$* * * \quad \mathrm{P}<0.001$.

untreated patient $(\mathrm{p}<0.05)$. The group on hydroxyurea treatments showed no significant difference when compared with untreated group $(p>0.05)$ or omega-3 treated group $(p>0.05)$, Fig. 6 .

\section{Discussion}

The anti-inflammatory effect of $n-3$ fatty acids is well documented [24]. However, to the best of our knowledge, no study investigated the effect of fatty acid supplementation on genetic and molecular markers of inflammation in patients with sickle cell disease. Findings of this study provide evidence that the observed beneficial effects of $n-3$ fatty acid supplementation on patients with SCD could be partially due to amelioration of chronic inflammation and increased blood cell adhesion, the major causative factors of vaso-occlusion and complications characterizing the disease $[25,26]$.

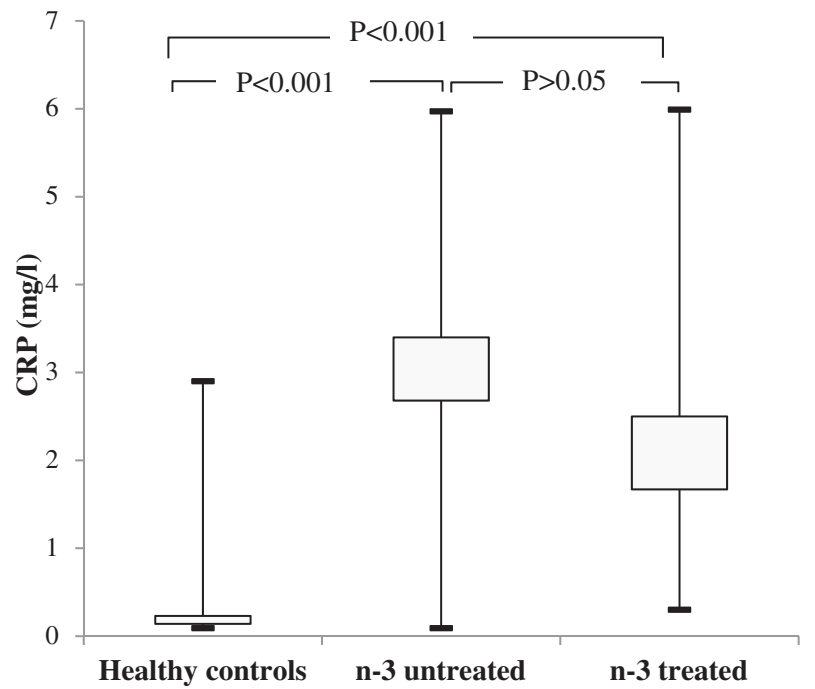

Fig. 1. C-reactive protein (CRP) concentration of HbSS patients $n-3$ treated, untreated and healthy controls.
The SCD patients and healthy who participated in this study were from common ethnic and socio-economic backgrounds. The patients were under regular management protocols and similar quality of care. Moreover, baseline and one-year samples were collected at the same season during the year. Supplementation with $n-3$ fatty acids resulted in more than twofold increase in EPA and DHA both in PE and PC. On the other hand, fatty acids of the placebo group remained comparatively constant apart from slight increase in total $n-6$ and decrease in EPA of PC phosphoglyceride. Therefore it is unlikely to account the observed results to factor(s) other than $n-3$ intervention or treatment with hydroxyurea.

Total white blood count and CRP are known markers of systemic global inflammatory activity. Consistent with the previous studies, sickle cell patients have elevated baseline values of TWBC and CRP $[27,28]$. These results provide additional evidence that SCD is a disease with an important inflammatory component [1].

The observed decrease in TWBC owing to $n-3$ fatty acids supplementation is constituent with findings obtained from conditions other than SCD [29-31] and patients with SCD [16]. It is tenable; this

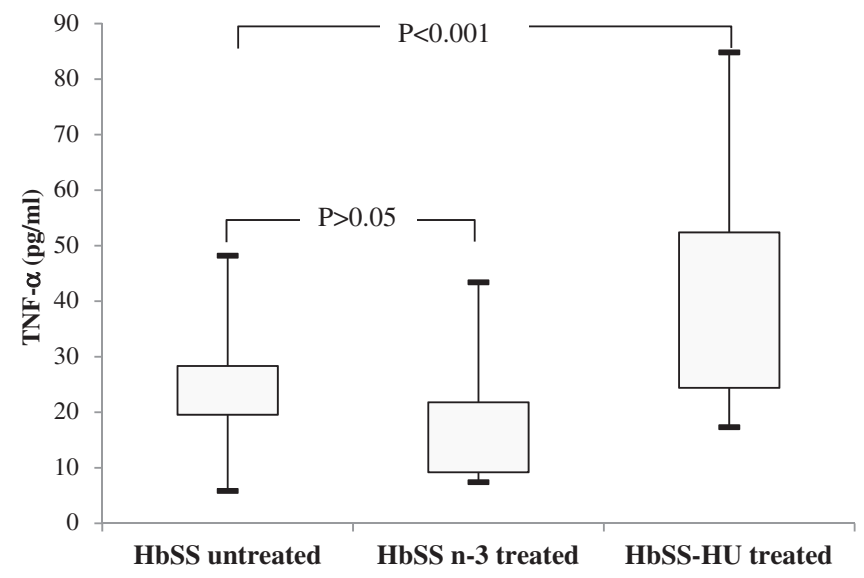

Fig. 2. Tumour necrosis factor- $\alpha$ (TNF- $\alpha$ ) concentration of SCD patients treated with $n-3$ fatty acids or hydroxyurea and untreated controls. 

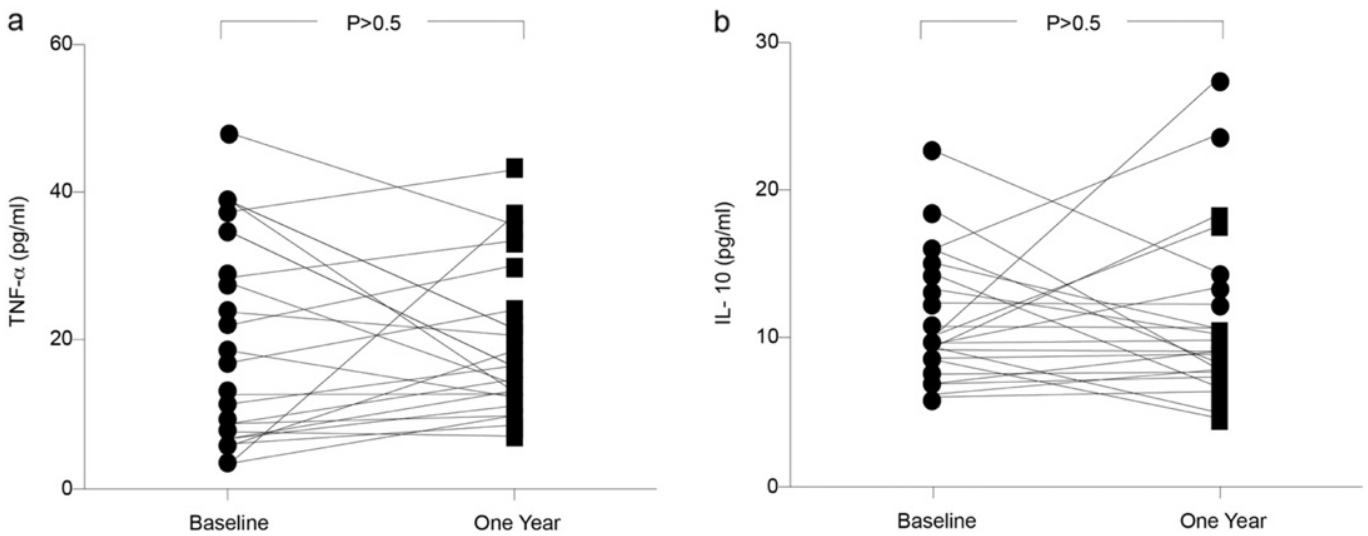

Fig. 3. Plasma TNF- $\alpha$ concentrations (a) and IL-10 concentrations (b) of patients with $n-3$ fatty acids before and after one year of supplementation with $n-3$ fatty acid.

reduction in blood cell count was a manifestation of an improved inflammatory state $[32,33]$ or diminished haemopoietic activity of the bone marrow [34]. On the other hand, treatment with $n-3$ fatty acids resulted in lower but not significant levels of CRP or platelet count compared to untreated patients. This finding is consistent with results reported from studies on healthy adults [35], patients with chronic nonautoimmune disease [36] and SCD patients [37]. It is possible that a larger sample size is needed to elucidate the effect of supplementation on variables of huge inter-individual variations such as platelet count.
TNF- $\alpha$ is a cytokine with a wide variety of actions that include activation of leukocytes, synthesis of acute phase proteins and the expression of adhesion molecules. Studies on the effect of HU treatment on plasma TNF- $\alpha$ level yielded controversial results [38,39]. In this study, HU treated patients had a high level of TNF- $\alpha$. Considering the fact that patients assigned to $\mathrm{HU}$ are those with a relatively severe type of disease [40], the observed high levels of TNF- $\alpha$ could be a mere reflection of the well-known heterogeneous biological effects of HU treatment in SCD [41].

a

Monocytes
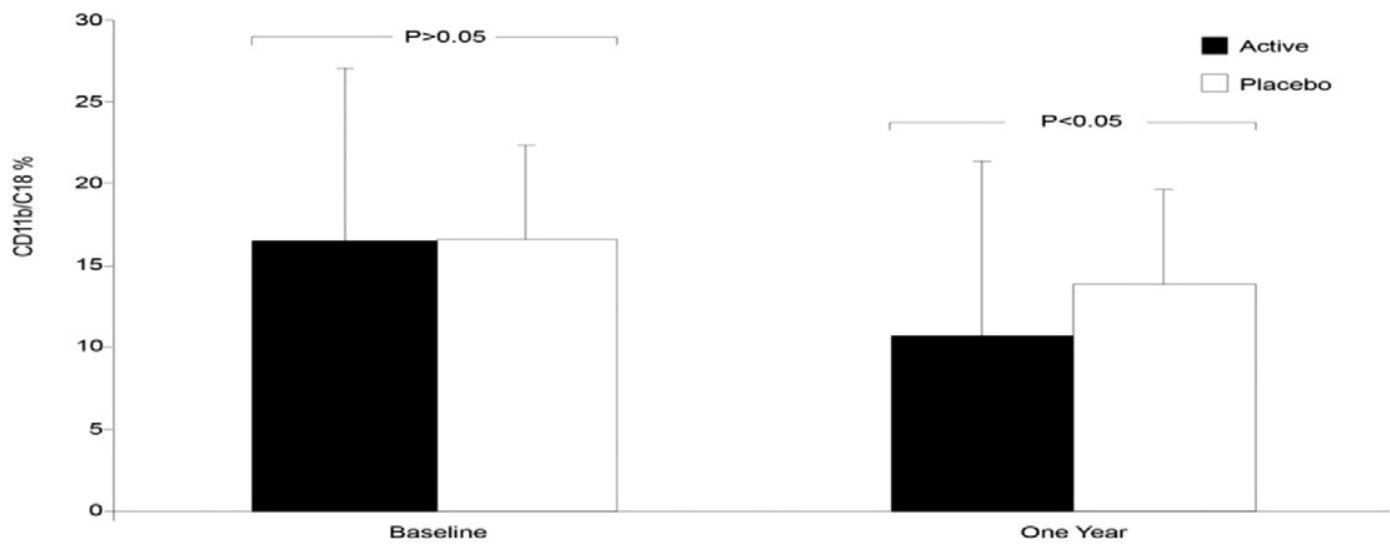

b
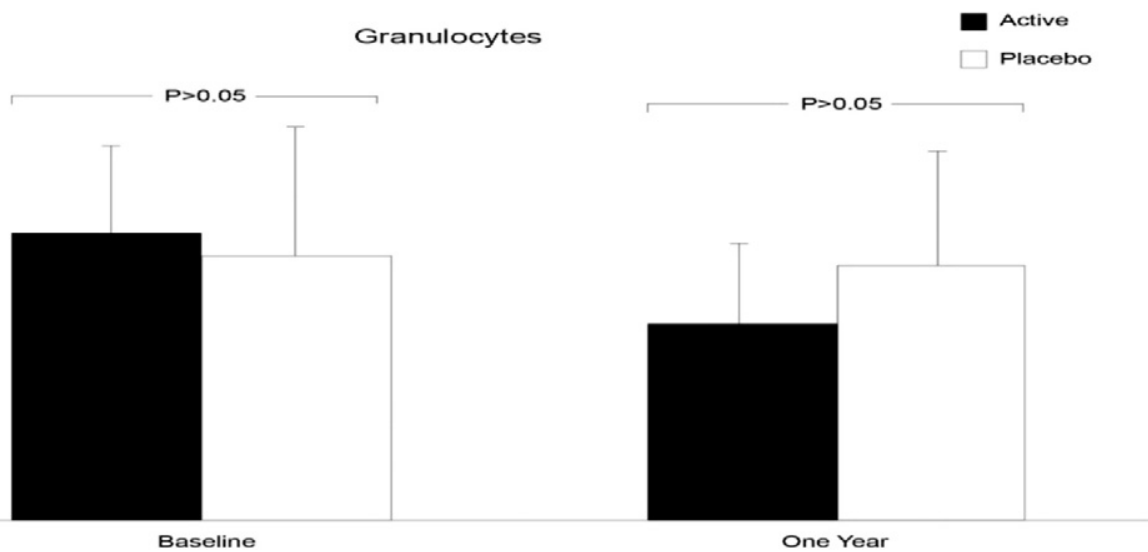

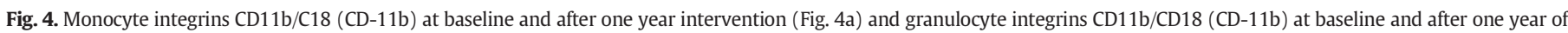
intervention (Fig. 4b). 


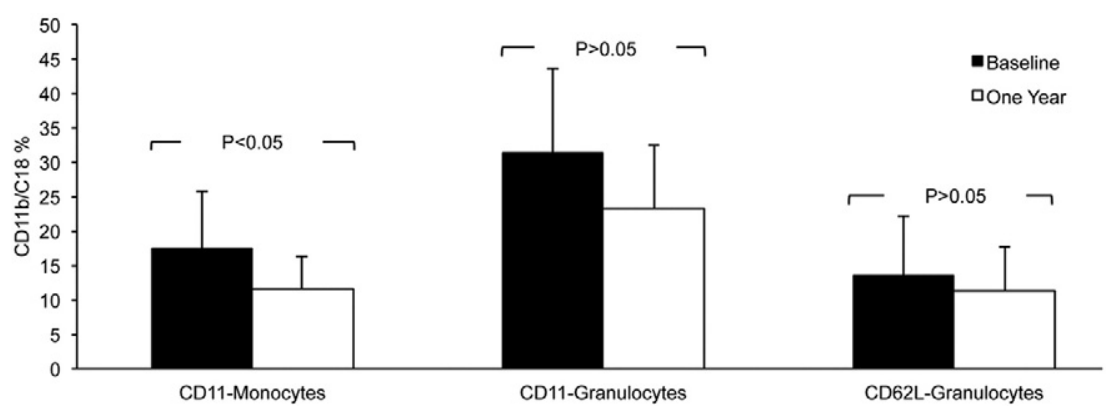

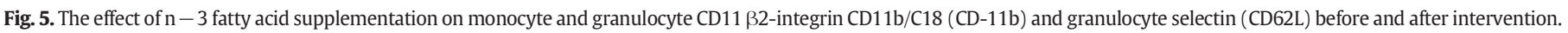

In accordance with the studies conducted on patients with diabetes mellitus [42,43], rheumatoid arthritis [44,45] and Crohn's disease [46], supplementation with $\mathrm{n}-3$ fatty acids showed no significant change on plasma levels of TNF- $\alpha$ or IL-10 [47]. Conversely, some studies that measured the effect of supplementation on cytokine production by monocytes [12,13] or local rather than systemic levels of cytokines showed significant effects [48]. This discrepancy between the systemic and cell or tissue-specific levels is intriguing. Though, it gives some indication that systemic plasma cytokine levels are not sensitive enough to reflect the tissue-specific immunological response to supplementation with $n-3$ fatty acids [47]. Moreover, as previously suggested [11], very high dose of $\mathrm{n}-3$ fatty acids might be necessary to achieve detectable systemic anti-inflammatory response.

It has been shown that the adhesive molecules involved in increased adhesiveness of granulocytes and monocytes and leukocytes interaction with endothelial cells are the cytokine-induced L-and P-selectin (CD62L), $\beta 2$-integrin CD11b/C18 (CD-11b) and LFA-1 (CD11a/CD18) [49-52]. L-selectin (CD62L) facilitates rolling and temporary arrest of circulating leukocytes on endothelium surface [53], whereas $\beta 2$ integrin (CD11b) is involved in subsequent stable adhesion [54,55]. Therefore, therapeutic approaches to reduce expression of CD62L and CD11B have been important strategies to prevent vaso-occlusion in sickle cell disease [50]. In vitro [56,57] and in vivo [13] studies in conditions other than SCD have revealed that supplementation with $n-3$ resulted in significant reduction in blood cell adhesive molecules. Interestingly, we observed a significant reduction of adhesive molecules in monocytes in the group supplemented with $n-3$ fatty acids, the finding which denotes improvement in SCD-associated chronic inflammatory state.

Experimental studies [10], and pilot clinical trials on patients with disease have shown that NF- $\kappa$ B inhibition is associated with significantly reduced leukocyte adhesion and improved microvascular blood flow [7]. Strikingly, in the current study supplementation with $n-3$ fatty acids, but not hydroxyurea, resulted in significant reduction in white blood cells' NF- $\kappa B$ gene expression in the patients with SCD. This result

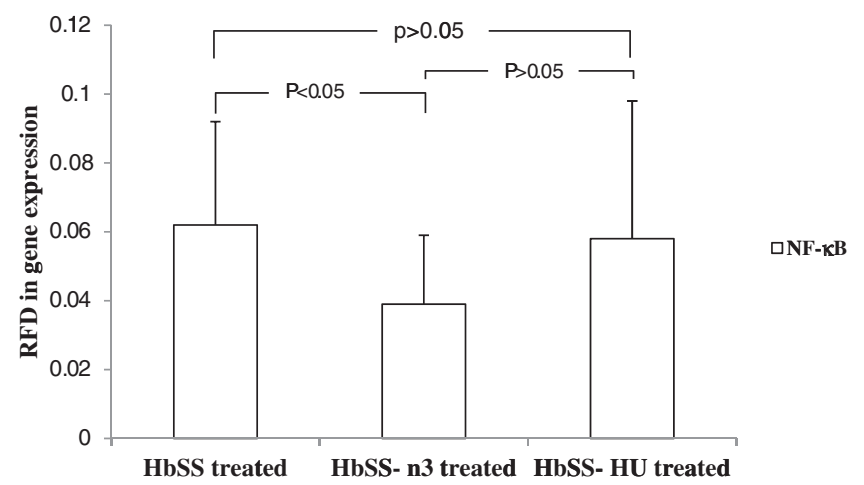

Fig. 6. Relative fold difference (RFD) of NF- $k B$ gene expression of $n-3$ treated and $n-3$ not-treated and hydroxyurea treated HbSS sickle cell patients. is in line with whole genome gene expression studies in adults supplemented with $n-3$ fatty acids $[58,59]$. Knowing that NF- $\kappa B$ pathway mediates oxidative stress response [60], the observed reduction in NF$\kappa B$ gene expression could be a reflection to the observed improvements in the patients' oxidative stress status after supplementation with $n-3$ fatty acids [19]. The results of the present study might also suggest pathways other than NF- $\kappa$ B gene involved in hydroxyurea well-documented anti-adhesive effects [9].

Chronic inflammation, intravascular haemolysis, imbalanced vascular nitric oxide (NO), oxidative stress are known factors that underlie vasculapathy-related complications in SCD $[61,62]$. Among these complications, pulmonary hypertension (PHT) and stroke stand out as the most prevalent and devastating. Interestingly, SCD patients with PHT have higher levels of markers of endothelial activation, coagulation activation and other inflammatory markers than SCD patients without PHT. Hence the clinical importance of the findings of this study, besides supporting previous reports about the positive therapeutic effect of $\mathrm{n}-3$ fatty acids in SCD $[16,18,19,37]$, that it suggests high DHA $\mathrm{n}-3$ supplement as a potential intervention to prevent PHT, stroke and other SCD vasculopathy-related complications.

One limitation of our study is that we did not measure the blood cells' cytokine levels. Therefore, it would be a justifiable analysis interest to focus on the effect of supplementation on tissue- specific pro- and anti-inflammatory cytokines, and fatty acids derived active metabolites of the orthodox and novel pathways [63]. Based on the results of the present study we might wish to suggest a relatively higher dosage of $\mathrm{n}-3$ for patients with SCD to achieve more potent systemic antiinflammatory effect.

In conclusion, the current study demonstrates that supplementation with $\mathrm{n}-3$ fatty acids mitigate some measures of inflammation and blood cell adhesion in patients with sickle cell disease. The results of this study provide some biological plausibility to $n-3$ therapeutic effects on patients with sickle cell disease, and support its use as a safe and effective treatment for acute and chronic complications of the disease.

\section{Conflict of interest}

The funding bodies had no influence on the study design, collection and analysis of data, interpretation of results or writing. The authors do not have a conflict of interest or financial relationships with the funding bodies.

\section{Acknowledgement}

We are grateful to Dr Bakhita Attallah and support staff of the Sickle Cell Disease Referral Clinic, Ibn-Aoaf Paediatric and Khartoum Teaching Hospitals (Sudan), and to Peter Clough, Efamol Limited UK, for his expert advice on the selection of the supplements used and for the support throughout the duration of this study. We are very grateful to Takemi Program in International Health, Harvard School of Public Health, Boston, USA for supporting A Daak to write the manuscript. 


\section{References}

[1] O.S. Platt, Sickle cell anemia as an inflammatory disease, J. Clin. Invest. 106 (2000) 337-338.

[2] D.K. Kaul, E. Finnegan, G.A. Barabino, Sickle red cell-endothelium interactions, Microcirculation 16 (2009) 97-111.

[3] S.H. Embury, The not-so-simple process of sickle cell vasoocclusion, Microcirculation 11 (2004) 101-113.

[4] R.P. Hebbel, Beyond hemoglobin polymerization: the red blood cell membrane and sickle disease pathophysiology, Blood 77 (1991) 214-237.

[5] P.S. Frenette, Sickle cell vaso-occlusion: multistep and multicellular paradigm, Curr. Opin. Hematol. 9 (2002) 101-106.

[6] D.C. Rees, T.N. Williams, M.T. Gladwin, Sickle-cell disease, Lancet 376 (2010) 2018-2031.

[7] A.A. Solovey, A.N. Solovey, J. Harkness, R.P. Hebbel, Modulation of endothelial cell activation in sickle cell disease: a pilot study, Blood 97 (2001) 1937-1941.

[8] A. Solovey, R. Kollander, A. Shet, L.C. Milbauer, S. Choong, A. Panoskaltsis-Mortari, B.R. Blazar, R.J. Kelm Jr., R.P. Hebbel, Endothelial cell expression of tissue factor in sickle mice is augmented by hypoxia/reoxygenation and inhibited by lovastatin, Blood 104 (2004) 840-846.

[9] C. Johnson, M.J. Telen, Adhesion molecules and hydroxyurea in the pathophysiology of sickle cell disease, Haematologica 93 (2008) 481-485.

[10] D.K. Kaul, X.D. Liu, S. Choong, J.D. Belcher, G.M. Vercellotti, R.P. Hebbel, Anti-inflammatory therapy ameliorates leukocyte adhesion and microvascular flow abnormalities in transgenic sickle mice, Am. J. Physiol. Heart Circ. Physiol. 287 (2004) H293-H301.

[11] P.C. Calder, Marine omega-3 fatty acids and inflammatory processes: Effects, mechanisms and clinical relevance, Biochim. Biophys. Acta (2014).

[12] G.E. Caughey, E. Mantzioris, R.A. Gibson, L.G. Cleland, M.J. James, The effect on human tumor necrosis factor alpha and interleukin 1 beta production of diets enriched in $\mathrm{n}-3$ fatty acids from vegetable oil or fish oil, Am. J. Clin. Nutr. 63 (1996) $116-122$

[13] K. Mayer, S. Meyer, M. Reinholz-Muhly, U. Maus, M. Merfels, J. Lohmeyer, F. Grimminger, W. Seeger, Short-time infusion of fish oil-based lipid emulsions, approved for parenteral nutrition, reduces monocyte proinflammatory cytokine generation and adhesive interaction with endothelium in humans, J. Immunol. 171 (2003) 4837-4843.

[14] A.A. Daak, K. Ghebremeskel, M.I. Elbashir, A. Bakhita, Z. Hassan, M.A. Crawford, Hydroxyurea therapy mobilises arachidonic acid from inner cell membrane aminophospholipids in patients with homozygous sickle cell disease, J. Lipids 2011 (2011) 718014.

[15] M. Aslan, G. Celmeli, F. Ozcan, A. Kupesiz, LC - MS/MS analysis of plasma polyunsaturated fatty acids in patients with homozygous sickle cell disease, Clin. Exp. Med. (2014).

[16] A.A. Daak, K. Ghebremeskel, Z. Hassan, B. Attallah, H.H. Azan, M.I. Elbashir, M. Crawford, Effect of omega-3 $(n-3)$ fatty acid supplementation in patients with sickle cell anemia: randomized, double-blind, placebo-controlled trial, Am. J. Clin. Nutr. 97 (2012) 37-44.

[17] I. Okpala, O. Ezenwosu, A. Ikefuna, A. Duru, B. Chukwu, A. Madu, T. Nwagha, S. Ocheni, O. Ibegbulam, I. Emodi, U. Anike, C. Nonyelu, C. Anigbo, K. Agu, I. Ajuba, A. Chukwura, O. Ugwu, U. Ololo, Addition of multimodal therapy to standard management of steady state sickle cell disease, ISRN Hematol. 2013 (2013) 236374.

[18] A. Tomer, S. Kasey, W.E. Connor, S. Clark, L.A. Harker, J.R. Eckman, Reduction of pain episodes and prothrombotic activity in sickle cell disease by dietary $\mathrm{n}-3$ fatty acids, Thromb. Haemost. 85 (2001) 966-974.

[19] A.A. Daak, K. Ghebremeskel, K. Mariniello, B. Attallah, P. Clough, M.I. Elbashir, Docosahexaenoic and eicosapentaenoic acid supplementation does not exacerbate oxidative stress or intravascular haemolysis in homozygous sickle cell patients, Prostaglandins Leukot. Essent. Fat. Acids 89 (2013) 305-311

[20] N.J. Wandersee, J.L. Maciaszek, K.M. Giger, M.S. Hanson, S. Zheng, Y. Guo, B. Mickelson, C.A. Hillery, G. Lykotrafitis, P.S. Low, N. Hogg, Dietary supplementation with docosahexanoic acid (DHA) increases red blood cell membrane flexibility in mice with sickle cell disease, Blood Cells Mol. Dis. 54 (2015) 183-188.

[21] P.C. Calder, $\mathrm{n}-3$ fatty acids, inflammation and immunity: new mechanisms to explain old actions, Proc. Nutr. Soc. 72 (2013) 326-336.

[22] J.F. Fahrmann, O.F. Ballester, G. Ballester, T.R. Witte, A.J. Salazar, B. Kordusky, K.G. Cowen, G. Ion, D.A. Primerano, G. Boskovic, J. Denvir, W.E. Hardman, Inhibition of nuclear factor kappa B activation in early-stage chronic lymphocytic leukemia by omega-3 fatty acids, Cancer Investig. 31 (2013) 24-38.

[23] K.I. Ataga, Novel therapies in sickle cell disease, Hematol. Am. Soc. Hematol. Educ. Program (2009) 54-61.

[24] P.C. Calder, The relationship between the fatty acid composition of immune cells and their function, Prostaglandins Leukot. Essent. Fat. Acids 79 (2008) 101-108.

[25] S.C. Cottin, T.A. Sanders, W.L. Hall, The differential effects of EPA and DHA on cardiovascular risk factors, Proc. Nutr. Soc. (2011) 1-17.

[26] R. Farzaneh-Far, W.S. Harris, S. Garg, B. Na, M.A. Whooley, Inverse association of erythrocyte $n-3$ fatty acid levels with inflammatory biomarkers in patients with stable coronary artery disease: The Heart and Soul Study, Atherosclerosis 205 (2009) 538-543.

[27] S. Krishnan, Y. Setty, S.G. Betal, V. Vijender, K. Rao, C. Dampier, M. Stuart, Increased levels of the inflammatory biomarker C-reactive protein at baseline are associated with childhood sickle cell vasocclusive crises, Br. J. Haematol. 148 (2010) 797-804.

[28] J.S. Mohan, G.Y. Lip, J. Wright, D. Bareford, A.D. Blann, Plasma levels of tissue factor and soluble E-selectin in sickle cell disease: relationship to genotype and to inflammation, Blood Coagul. Fibrinolysis 16 (2005) 209-214.
[29] Y. Park, W.S. Harris, Dose-dependent effects of $\mathrm{n}-3$ polyunsaturated fatty acids on platelet activation in mildly hypertriglyceridemic subjects, J. Med. Food 12 (2009) 809-813.

[30] T. Hamazaki, R. Nakazawa, S. Tateno, H. Shishido, K. Isoda, Y. Hattori, T. Yoshida, T. Fujita, S. Yano, A. Kumagai, Effects of fish oil rich in eicosapentaenoic acid on serum lipid in hyperlipidemic hemodialysis patients, Kidney Int. 26 (1984) 81-84.

[31] V.R. Mukaro, M. Costabile, K.J. Murphy, C.S. Hii, P.R. Howe, A. Ferrante, Leukocyte numbers and function in subjects eating $\mathrm{n}-3$ enriched foods: selective depression of natural killer cell levels, Arthritis Res. Ther. 10 (2008) R57.

[32] K.I. Ataga, E.P. Orringer, Hypercoagulability in sickle cell disease: a curious paradox Am. J. Med. 115 (2003) 721-728.

[33] J.W. Semple, J. Freedman, Platelets and innate immunity, Cell. Mol. Life Sci. 67 (2010) 499-511.

[34] J. Tancabelic, S. Sheth, M. Paik, S. Piomelli, Serum transferrin receptor as a marker of erythropoiesis suppression in patients on chronic transfusion, Am. J. Hematol. 60 (1999) 121-125.

[35] M.R. Flock, A.C. Skulas-Ray, W.S. Harris, T.L. Gaugler, J.A. Fleming, P.M. Kris-Etherton, Effects of supplemental long-chain omega-3 fatty acids and erythrocyte membrane fatty acid content on circulating inflammatory markers in a randomized controlled trial of healthy adults, Prostaglandins Leukot. Essent. Fat. Acids 91 (2014) 161-168.

[36] K. Li, T. Huang, J. Zheng, K. Wu, D. Li, Effect of marine-derived $n-3$ polyunsaturated fatty acids on C-reactive protein, interleukin 6 and tumor necrosis factor alpha: a meta-analysis, PLoS One 9 (2014) e88103.

[37] I. Okpala, O. Ibegbulam, A. Duru, S. Ocheni, I. Emodi, A. Ikefuna, G. Umar, I. Asinobi, A. Madu, A. Okoye, T. Nwagha, U. Oguonu, I. Uamai, O. Agwu, C. Nonyelu, U. Anike, K. Agu, C. Anigbo, A. Chukwura, O. Ugwu, S. Herrada, Pilot study of omega-3 fatty acid supplements in sickle cell disease, APMIS 119 (2011) 442-448.

[38] C. Lanaro, C.F. Franco-Penteado, D.M. Albuqueque, S.T. Saad, N. Conran, F.F. Costa, Altered levels of cytokines and inflammatory mediators in plasma and leukocytes of sickle cell anemia patients and effects of hydroxyurea therapy, J. Leukoc. Biol. 85 (2009) 235-242.

[39] M.R. Laurentino, P.A.F. Maia, M.C. Barbosa, I.C. Bandeira, L.B. Rocha, R.P. Goncalves, Influence of betaS-globin haplotypes and hydroxyurea on tumor necrosis factoralpha levels in sickle cell anemia, Rev. Bras. Hematol. Hemoter. 36 (2014) 121-125.

[40] R.E. Ware, Hydroxycarbamide: clinical aspects, C. R. Biol. 336 (2013) 177-182.

[41] R.E. Ware, J.M. Despotovic, N.A. Mortier, J.M. Flanagan, J. He, M.P. Smeltzer, A.C. Kimble, B. Aygun, S. Wu, T. Howard, A. Sparreboom, Pharmacokinetics, pharmacodynamics, and pharmacogenetics of hydroxyurea treatment for children with sickle cell anemia, Blood 118 (2011) 4985-4991.

[42] T.A. Mori, R.J. Woodman, V. Burke, I.B. Puddey, K.D. Croft, L.J. Beilin, Effect of eicosapentaenoic acid and docosahexaenoic acid on oxidative stress and inflammatory markers in treated-hypertensive type 2 diabetic subjects, Free Radic. Biol. Med. 35 (2003) 772-781.

[43] J. Molvig, F. Pociot, H. Worsaae, L.D. Wogensen, L. Baek, P. Christensen, T. MandrupPoulsen, K. Andersen, P. Madsen, J. Dyerberg, et al., Dietary supplementation with omega-3-polyunsaturated fatty acids decreases mononuclear cell proliferation and interleukin-1 beta content but not monokine secretion in healthy and insulindependent diabetic individuals, Scand. J. Immunol. 34 (1991) 399-410.

[44] T. Sundrarjun, S. Komindr, N. Archararit, W. Dahlan, O. Puchaiwatananon, S. Angthararak, U. Udomsuppayakul, S. Chuncharunee, Effects of $n-3$ fatty acids on serum interleukin-6, tumour necrosis factor-alpha and soluble tumour necrosis factor receptor p55 in active rheumatoid arthritis, J. Int. Med. Res. 32 (2004) 443-454.

[45] O. Adam, C. Beringer, T. Kless, C. Lemmen, A. Adam, M. Wiseman, P. Adam, R. Klimmek, W. Forth, Anti-inflammatory effects of a low arachidonic acid diet and fish oil in patients with rheumatoid arthritis, Rheumatol. Int. 23 (2003) 27-36.

[46] T.M. Trebble, N.K. Arden, S.A. Wootton, P.C. Calder, M.A. Mullee, D.R. Fine, M.A Stroud, Fish oil and antioxidants alter the composition and function of circulating mononuclear cells in Crohn disease, Am. J. Clin. Nutr. 80 (2004) 1137-1144.

[47] J.W. Sijben, P.C. Calder, Differential immunomodulation with long-chain $n-3$ PUFA in health and chronic disease, Proc. Nutr. Soc. 66 (2007) 237-259.

[48] W. Matsuyama, H. Mitsuyama, M. Watanabe, K. Oonakahara, I. Higashimoto, M. Osame, K. Arimura, Effects of omega-3 polyunsaturated fatty acids on inflammatory markers in COPD, Chest 128 (2005) 3817-3827.

[49] I. Okpala, The intriguing contribution of white blood cells to sickle cell disease a red cell disorder, Blood Rev. 18 (2004) 65-73.

[50] A.A. Canalli, C.F. Franco-Penteado, S.T. Saad, N. Conran, F.F. Costa, Increased adhesive properties of neutrophils in sickle cell disease may be reversed by pharmacological nitric oxide donation, Haematologica 93 (2008) 605-609.

[51] A. Assis, N. Conran, A.A. Canalli, I. Lorand-Metze, S.T. Saad, F.F. Costa, Effect of cytokines and chemokines on sickle neutrophil adhesion to fibronectin, Acta Haematol. 113 (2005) 130-136.

[52] P. Tan, F.W. Luscinskas, S. Homer-Vanniasinkam, Cellular and molecular mechanisms of inflammation and thrombosis, Eur. J. Vasc. Endovasc. Surg. 17 (1999) 373-389.

[53] H.J. Strausbaugh, P.G. Green, E. Lo, K. Tangemann, D.B. Reichling, S.D. Rosen, J.D. Levine, Painful stimulation suppresses joint inflammation by inducing shedding of L-selectin from neutrophils, Nat. Med. 5 (1999) 1057-1061.

[54] C. Nathan, Points of control in inflammation, Nature 420 (2002) 846-852.

[55] E. Chavakis, E.Y. Choi, T. Chavakis, Novel aspects in the regulation of the leukocyte adhesion cascade, Thromb. Haemost. 102 (2009) 191-197.

[56] K. Mayer, M. Merfels, M. Muhly-Reinholz, S. Gokorsch, S. Rosseau, J. Lohmeyer, N. Schwarzer, M. Krull, N. Suttorp, F. Grimminger, W. Seeger, Omega-3 fatty acids suppress monocyte adhesion to human endothelial cells: role of endothelial PAF generation, Am. J. Physiol. Heart Circ. Physiol. 283 (2002) H811-H818.

[57] R. De Caterina, P. Libby, Control of endothelial leukocyte adhesion molecules by fatty acids, Lipids 31 (1996) S57-S63 (Suppl.). 
[58] K.L. Weaver, P. Ivester, M. Seeds, L.D. Case, J.P. Arm, F.H. Chilton, Effect of dietary fatty acids on inflammatory gene expression in healthy humans, J. Biol. Chem. 284 (2009) 15400-15407.

[59] S.M. Ulven, M.C. Myhrstad, K.B. Holven, Marine $n-3$ fatty acids and gene expression in peripheral blood mononuclear cells, Curr. Cardiovasc. Risk Rep. 8 (2014) 412

[60] I. Rudkowska, A.M. Paradis, E. Thifault, P. Julien, A. Tchernof, P. Couture, S. Lemieux, O. Barbier, M.C. Vohl, Transcriptomic and metabolomic signatures of an $n-3$ polyunsaturated fatty acids supplementation in a normolipidemic/normocholesterolemic Caucasian population, J. Nutr. Biochem. 24 (2013) 54-61.
[61] K.P. Potoka, M.T. Gladwin, Vasculopathy and pulmonary hypertension in sickle cell disease, Am. J. Physiol. Lung Cell. Mol. Physiol. (2014) (ajplung 0025202014 ).

[62] P. Connes, S. Verlhac, F. Bernaudin, Advances in understanding the pathogenesis of cerebrovascular vasculopathy in sickle cell anaemia, Br. J. Haematol. 161 (2013) 484-498.

[63] R. De Caterina, $\mathrm{n}-3$ fatty acids in cardiovascular disease, N. Engl. J. Med. 364 (2011) 2439-2450. 